\title{
Spatial alteration of fragmented landscape in evergreen and semi- evergreen rainforest: A case study in Chittagong Hill Tracts, Bangladesh
}

\author{
MASRURA MAMNUN ${ }^{1, \varphi}$, SADDAM HOSSEN ${ }^{2, \% \varphi}$ \\ ${ }^{1}$ Institute of Forestry and Environmental Sciences, University of Chittagong, Chittagong-4331, Bangladesh, \\ remail: masrurameem50@gmail.com \\ ${ }^{2}$ Department of Forestry and Environmental Science, Rangamati Science and Technology University. Rangamati-4500, Bangladesh \\ Tel.: +8801913291487, `email: saddamhossen.cu@gmail.com
}

Manuscript received: 11 November 2020. Revision accepted: 21 January 2021.

\begin{abstract}
Mamnun M, Hossen S. 2021. Spatial alteration of fragmented landscape in evergreen and semi-evergreen rainforest: A case study in Chittagong Hill Tracts, Bangladesh. Asian J For 5: 17-27. Evergreen and semi-evergreen forests in Bangladesh are important areas that hold a large number of biodiversity. Yet, these unique forest types are pressured by various human activities in the last decades, resulting in deforestation, forest degradation and fragmentation. The principal aim of the study was to explore the level of fragmentation and underlying drivers in forests of Bandarban Sadar Upazila, Chittagong Division, Bangladesh from 1988-2018. The ArcGIS v10.5 and ERDAS Imagine v15 software were used to process satellite imageries and assess quantitative data. The study revealed that the area under forest land decreased very rapidly; it was lost about 7165.13 ha and the annual destruction rate was $17.92 \%$. The edge density of forest area and agricultural crops rapidly increased from 1988-2018, while barren land and water bodies were almost consistent. Forest land became fragmented as its total edge area increased by $275.87 \%$ from $16469.6 \mathrm{~km}$ in 1988 to $61905 \mathrm{~km}$ in 2018. There was gradual decline in Shannon Diversity Index from 1988 (1.004), 2003 (0.878), and 2018 (0.615). Among the different factors, agro-horticultural plantation was the main factor for reduction in landscape diversity. This analytic study would help policymakers take necessary steps for sustainable forest management.
\end{abstract}

Keywords: Forest fragmentation, GIS, land-use, landscape metrics, patch

\section{INTRODUCTION}

Tropical rainforests cover only $7 \%$ of the earth's land surface, however, they have the highest amount of species diversity which contributes to almost $50 \%$ of the world's wildlife (Tchoumbou et al. 2020). Tropical forests are also one of the most important carbon sinks which store about $25 \%$ of terrestrial carbon (Zapfack et al. 2020). Nonetheless, species extinction and climate change are the most significant problem in tropical forests (Harper et al. 2007, Echeverria et al. 2008). Huge areas of rainforests are threatened due to deforestation, fragmentation, overexploitation, and climate change which vary from region to region (Bhusal et al. 1998, Morris 2010).

Fragmented landscape corroborates habitat loss and alters spatial characteristics and configuration, resulting in changes in physical and biological factors in a forest environment (Hansen et al. 2001, Jha et al. 2005). Fragmentation results in an extreme level of edge effects of the remaining forests area with strong differences between habitat near the edge and away from edges (Donovan et al. 1997, Broadbent et al. 2008). The effects of habitat fragmentation on species richness are often predicted by the landscape matrix (Öckinger et al. 2012). Within the last century, the increasing level of fragmentation associated with the rapid land-use change has made the landscape as a crucial and auxiliary scale of studies in wildlife ecology and forest management (Rodewald 2003). Landscape metrics are effectively applied to understand phenomena including the measurement of environmental change, landscape change, and forest fragmentation measurement (Hansen et al. 2001). Spatial or landscape metrics can be used to measure the numerous aspects of the land cover/land-use pattern including composition, spatial configuration, and spatial neighborhood of the land cover/land-use or landscape in a given area (Kowe et al. 2015). Different types of matrix are utilized in forest fragmentation study, among them the most common metrics are used to analyze forest fragmentation at the category or patch type-level include Number of Patches, Mean Patch Size, Patch Shape, Edge Density/Total Edge Distance, Mean Core Area, Patch Density, Fractal Dimension, Interpatch Distance and Interspersion and Juxtaposition (Hansen et al. 2001).

As one of the forest-poor countries in the world, Bangladesh has forest area $10.96 \%$ of its total land and it is struggling to conserve it (Baten et al. 2010). Among them, $4.54 \%$ of the country's total forests are evergreen and semievergreen forests covered with Chittagong Hill Tracts are included in this category. Like other mountainous regions of Asia, Chittagong Hill Tracts (CHT) of Bangladesh are also facing a great level of degradation, especially in recent four decades. The natural resources in this area have been exploited enormously to inappropriate land-use systems such as shifting cultivation associated with incendiary fires, population pressure, the encroachment of reserve forests, soil erosion, agroforestry practices, and commercial teak plantation (Rasul et al. 2004; Rasul and Thapa 2006; 
Biswas et al. 2012). As a result, forest areas in CHT are cleared, degraded, and fragmented.

So far, there is no study that investigates the fragmentation phenomena occurring in CHT. Therefore, the aim of the study was to explore the level of fragmentation in forests of Bandarban Sadar Upazila, Chittagong Hill Tracts using fragmentation matrices as well as to elucidate drivers related to fragmentation. The result of the study will provide insight into the fragmentation and underlying drivers in CHT which can help the government, organizations associated with natural resources management, policymakers, and other researchers to take necessary steps for sustainable management in the future.

\section{MATERIALS AND METHODS}

\section{Description of the study area}

The study area was Bandarban Sadar Upazila District, Chittagong Division, Bangladesh located at $21^{\circ} 55^{\prime}$ and $22^{\circ} 22^{\prime} \mathrm{N}$ and $92^{\circ} 08^{\prime}$ and $92^{\circ} 20^{\prime} \mathrm{E}$, having an area of about $501.99 \mathrm{~km}^{2}$. The Upazila is bounded by Rajasthali Upazila on the North, Lama Upazila on the South, Rowangchhari and Ruma Upazilas on the East, and Rangunia, Satkania and Lohagara Upazilas on the West and is bordered by Cox's Bazar, Chittagong, Rangamati and Khagrachari. On the other side of the $129 \mathrm{~km}$, international border lies Chin and Arakan provinces of Myanmar. It consists of 5 unions namely Rajbila Union, Kuhalong Union, Bandarban Sadar Union, Swalak, and Tankabati (Figure 1).

\section{Digital data collection and processing}

This study used multi-temporal satellite imagery data provided by USGS (United States Geological Survey) for
Landsat 8 OLI-TIRS (Operational Land Imager/ Thermal Infrared Sensor), Landsat 5 TM (Thematic Mapper) of the year 2018, 2003, and 1988 for visual image interpretation, land-use identification and land-use classification. Cloudfree satellite imagery during winter season was selected (November-February) to get accurate data for classification. The spatial resolution of Landsat 2 was $60 \mathrm{~m}$ and $30 \mathrm{~m}$ for Landsat 5 and 8 (Table 1). Landsat 8 raw image constitutes 11 bands and only 5,4,3 bands for Landsat 8 and 4,3,2 bands for both Landsat 5 and Landsat 2 were used. Composite layer of these 3 bands was created in Arc GIS 10.5, the pictures were then projected and clipped by using subset tools using the shapefile of Bandarban Sadar Upazila. A complete of 47,290.05 hectares (ha) of land was estimated for the entire Bandarban Sadar Upazila after supervised image classification using ERDAS Imagine v15.

\section{Land-use and land cover change detection process}

During June 2018-December 2018, a field survey was conducted within the study area to record specific land-use categories according to their latitude and longitude. A total of 500 GPS point locations were taken using convenient sampling. The land use of study area was classified into 5 groups including croplands, barren lands, settlements, water bodies and forest areas. The collected land-use data were used to determine the color tone of 2018 Landsat 8 images while training dataset. Afterward, maximum likelihood classification (MLC) was used for LULC assessment. After land-use classification, forest areas from supervised classification were exported to raster through spatial analysis tools in Arc GIS 10.5 and converted from raster to polygon in Arc map 10.5.

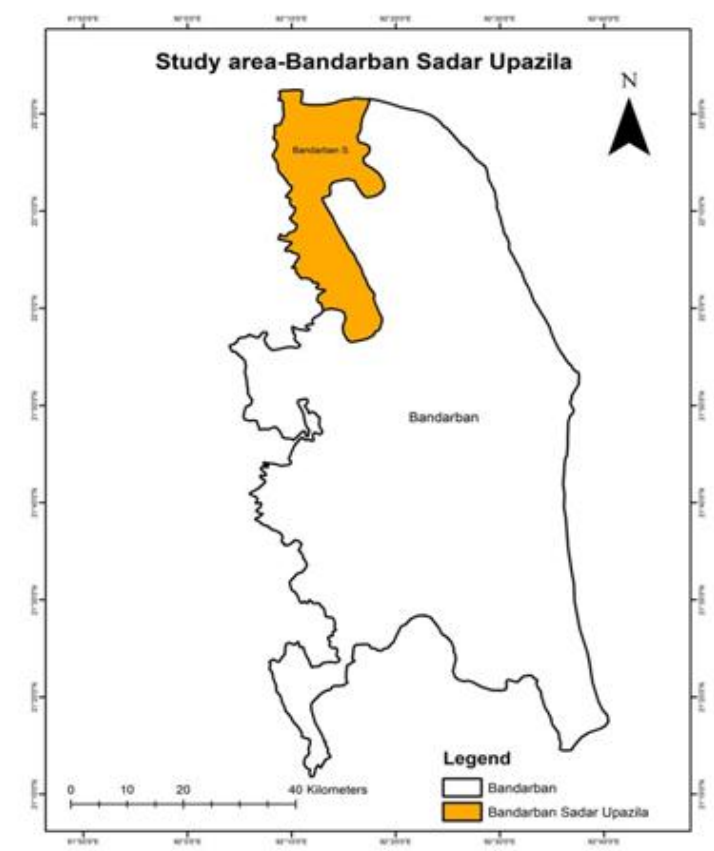

Figure 1. Study area of Bandarban Sadar Upazila District, Chittagong Division, Bangladesh 
Table 1. Detailed information about satellite images

\begin{tabular}{llllll}
\hline Satellite & Sensor & Path/row & Acquisition date & Spatial resolution $(\mathbf{m})$ & Spectral bands $(\boldsymbol{\mu m})$ \\
\hline Landsat 8 & OLI-TIRS & $136 / 44$ & $29-01-2018$ & $30 \times 30$ & B2-Visible Blue: $0.450-0.515 \mu \mathrm{m}$ \\
& & & & $\begin{array}{l}\text { B3-Visible Green: } 0.525-0.600 \mu \mathrm{m} \\
\text { B4-Visible Red: } 0.630-0.680 \mu \mathrm{m}\end{array}$ \\
& & & & B5-Near-infrared: $0.845-0.885 \mu \mathrm{m}$ \\
Landsat 5 & TM & $146 / 44$ & $20-11-2003$ & $30 \times 30$ & B2-Visible Green: $0.52-0.60 \mu \mathrm{m}$ \\
& & & & B3-Visible Red: $0.63-0.69 \mu \mathrm{m}$ \\
Landsat 5 & TM & \multirow{2}{*}{$146 / 44$} & $12-12-1988$ & $30 \times 30$ & B4-Near-infrared: $0.76-0.90 \mu \mathrm{m}$ \\
& & & & B2-Visible Green: $0.52-0.60 \mu \mathrm{m}$ \\
& & & & B3-Visible Red: $0.63-0.69 \mu \mathrm{m}$ \\
& & & B4-Near-infrared: $0.76-0.90 \mu \mathrm{m}$ \\
\hline
\end{tabular}

\section{Landscape configuration changes and fragmentation analysis}

FRAGSTATS and Patch analysts programs were used to explore the landscape patches and modeling of attributes related to patches. This spatial pattern analysis software is useful in determining habitat modeling for biodiversity conservation and forest management. Vector polygon data/ raster-based data derived from the years 2018, 2003, and 1988 were given as input metrics for measuring and quantifying landscape characteristics and their changes in growth dynamics (Table 2).

\section{Probability mapping using satellite imagery and topographic variables to analyze landscape diversity}

A probability map was made to classify different agrohorticultural practices within the study area. The probability map mainly represents the high suitability of environmental conditions for particular agro-horticultural practices. For tree species classification, probability mapping using primarily optical multispectral sensor like Landsat images were employed and in the next steps second (the topographic variables) from a digital elevation model (DEM) was used and geographical information systems (GIS) data from study area applied to make the probability map more accurate. For the first set of variables, a Landsat 8 image from USGS earth explorer was used (Figure 2).

Table 2. Quantifying changes in landscape configuration and composition for fragmentation analysis (class-level metrics)

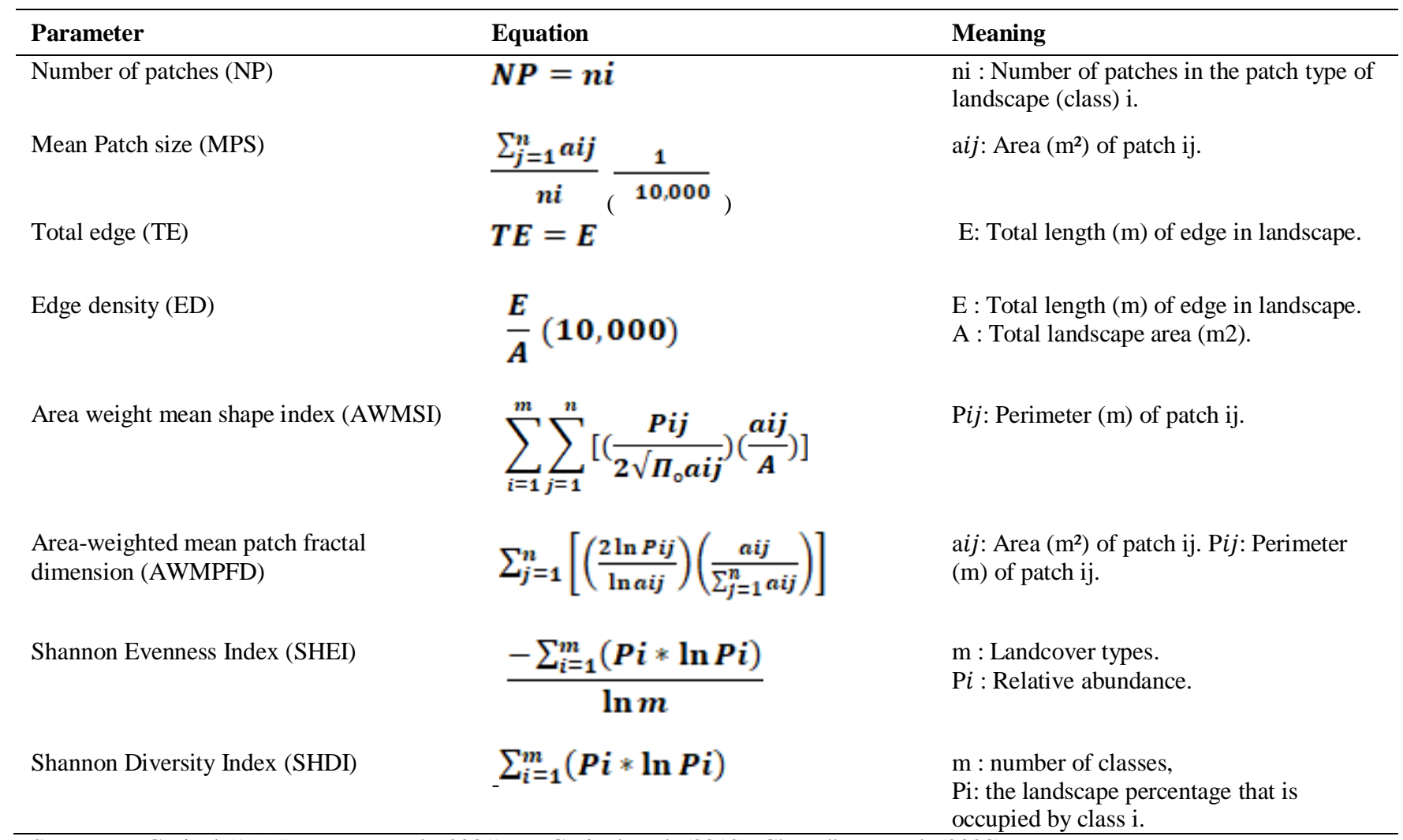



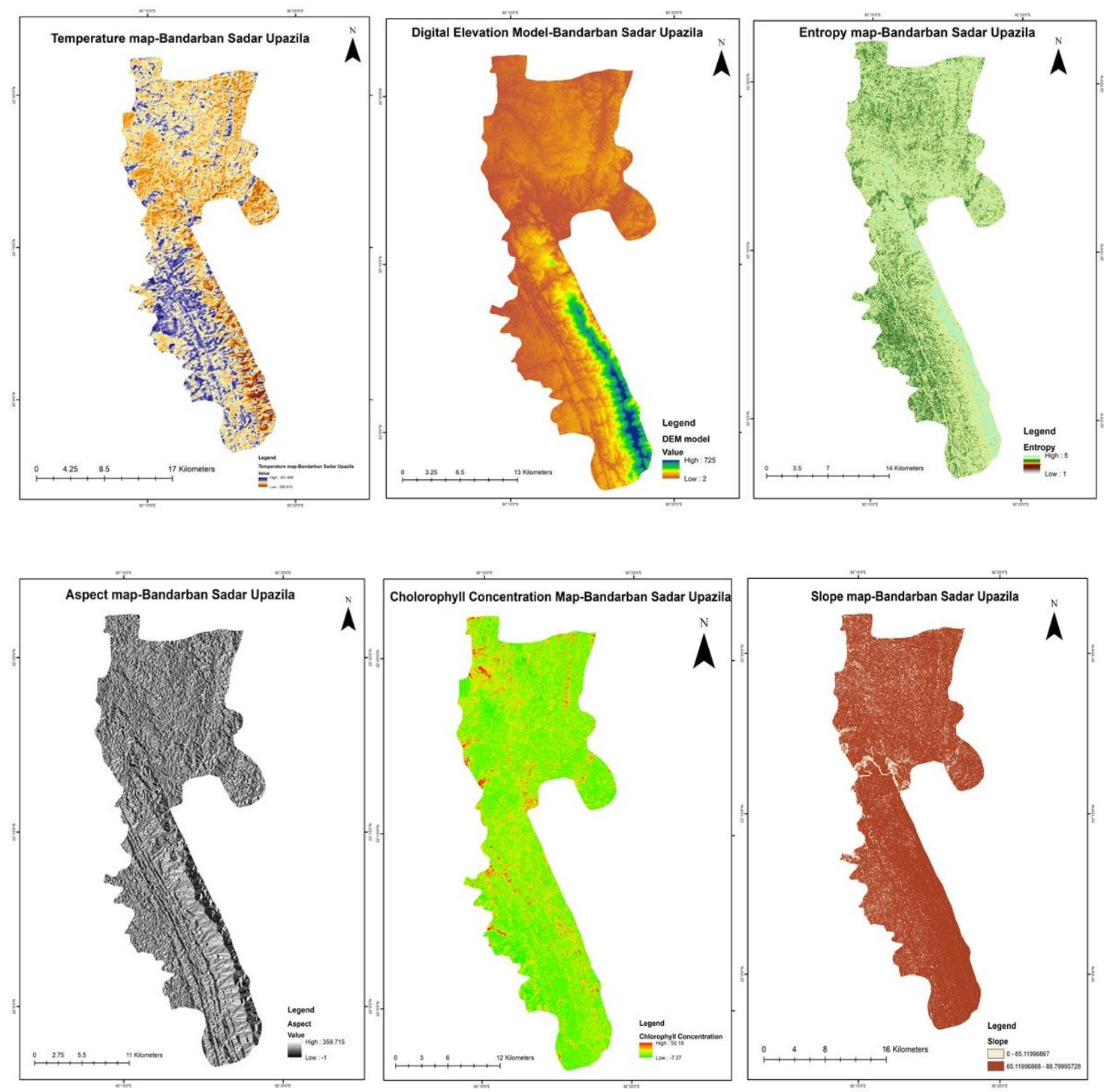

Figure 2. Model inputs to develop probability map to classify different agro-horticultural practices

To derive the topographic variables, the Global Digital Elevation Model (GDEM) version 2 data with a resolution of $30 \mathrm{~m}$ was obtained from the advanced spaceborne thermal emission and reflection radiometer (ASTER) that is operated by the National Aeronautics and Space Administration (NASA). By applying topographic variables, the logistic probability model was calculated, whose accuracy is more than the forest inventory maps (Chianga et al. 2016). For the study, maps of temperature, slope, aspect, chlorophyll and entropy of the study area were also used (Figure 2). Field level survey data for ground truth inventory map was overlapped upon entropy map and in this way, probability map for various agrohorticultural practices and plantations of the study area was prepared. After observing the classification result and comparing it with the tree species inventory, the foremost dominant practices within the study area were found to be teak plantations. In the study area, 7 main vegetation types viz. agroforestry, horticultural, fast-growing forest tree species plantation, teak plantation, jhum cultivation, homestead forestry and bamboo were found at the study site.

\section{RESULTS AND DISCUSSION}

\section{Relative changes of land-use in Bandarban Sadar Upazila}

Land-use mapping of Bandarban Sadar Upazila provided spatial distribution of land-use categories and land-use changes over the past 30 years (Figure 3 ). Table 3 and Table 4 show relative changes in Bandarban Sadar Upazila land-use from 1988-2018. Three trends were noticed from the results viz (i) proportion of area under barren land and settlements continuously increased from $2.53 \%$ and $1.57 \%$ respectively in 1988 to $10.42 \%$ and $5.33 \%$ respectively in 2018; (ii) percentage of forest areas 
were continuously declined from $84.56 \%$ in 1988 to $69.41 \%$ in 2018 ; (iii) while proportion of agricultural crops peaked in $2003(13.66 \%)$ from $1988(8.06 \%)$ and again decreased to $11.74 \%$ in 2018 and percentage cover of waterbody decreased to $2.72 \%$ in 2003 from $3.28 \%$ in 1988 , however, it again increased to $3.10 \%$ in 2018.

Table 4 shows land-use change from 1988 to 2018. During this period, agricultural land area increased by
$45.66 \%$ (58.01 hectares), barren land $312.39 \%$ and settlement $239.10 \%$. On the other hand, forest land area decreased very rapidly (238.83-hectare annual rate of change) and 7165.13 ha of forest land was lost during 1988-2018. The area of waterbody decreased by $5.47 \%$ (84.77 hectares).

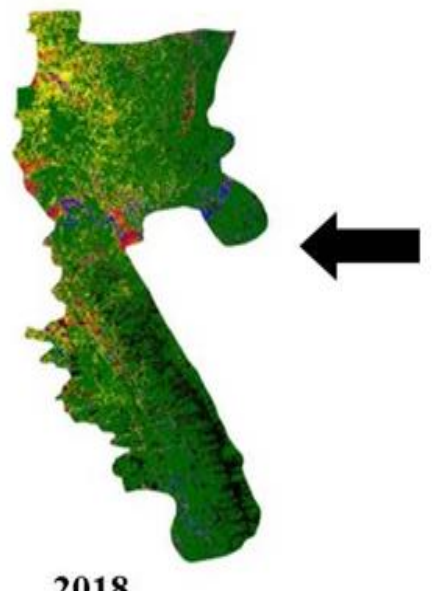

2018

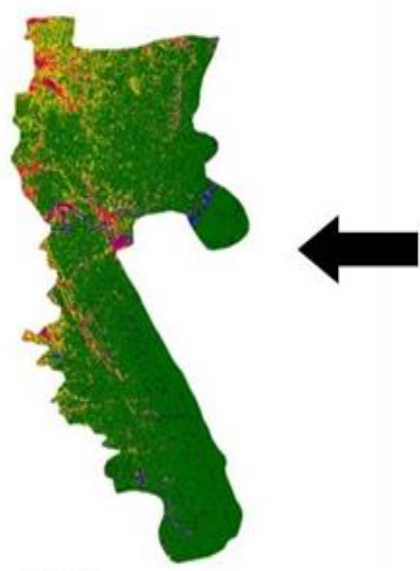

2003

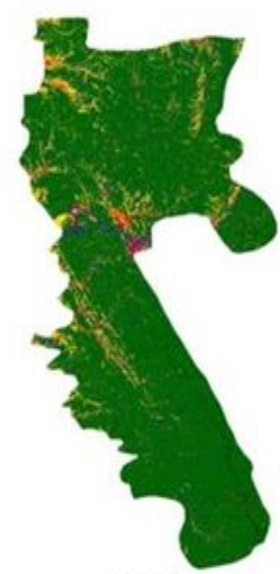

1988

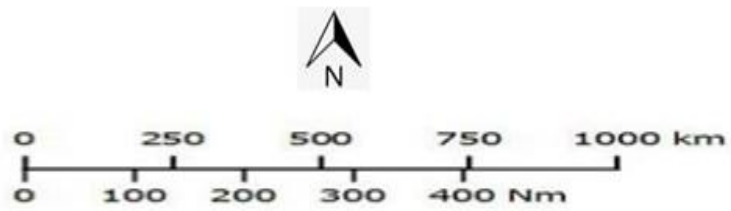

Legend

Settlemen

Agricultural crops

Barren land

Water body

Forest area

Figure 3. Relative changes of land-use from 1988-2018 of Bandarban Sadar Upazila, Bangladesh

Table 3. Land-use pattern of Bandarban Sadar Upazila, Bangladesh (1988-2018)

\begin{tabular}{lcccccc}
\hline Land-use category & \multicolumn{2}{c}{$\mathbf{1 9 8 8}$} & \multicolumn{2}{c}{$\mathbf{2 0 0 3}$} & \multicolumn{2}{c}{$\mathbf{2 0 1 8}$} \\
\cline { 2 - 6 } & Area (ha) & \% & Area (ha) & \% & Area (ha) & \% \\
\hline Agricultural crops & 3811.92 & 8.06 & 6461.91 & 13.66 & 5552.48 & 11.74 \\
Barren land & 1194.85 & 2.53 & 2704.95 & 5.72 & 4927.41 & 10.42 \\
Forest area & 39989.29 & 84.56 & 35078.13 & 74.18 & 32824.16 & 69.41 \\
Settlement & 743.11 & 1.57 & 1760.37 & 3.72 & 2519.89 & 5.33 \\
Waterbody & 1550.88 & 3.28 & 1284.69 & 2.72 & 1466.11 & 3.10 \\
\hline
\end{tabular}

Table 4. Land-use change assessment of Bandarban Sadar Upazila, Bangladesh from 1988 to 2018

\begin{tabular}{|c|c|c|c|c|c|c|c|c|c|}
\hline \multirow[b]{2}{*}{ Land-use category } & \multicolumn{3}{|c|}{ Land-use change: $1988-2003$} & \multicolumn{3}{|c|}{ Land-use change: $2003-2018$} & \multicolumn{3}{|c|}{ Land-use change: $1988-2018$} \\
\hline & $\begin{array}{l}\text { Changed } \\
\text { area (ha) }\end{array}$ & $\%$ change & $\begin{array}{l}\text { Annual } \\
\text { rate of } \\
\text { change }\end{array}$ & $\begin{array}{l}\text { Changed } \\
\text { area (ha) }\end{array}$ & $\%$ change & $\begin{array}{l}\text { Annual } \\
\text { rate of } \\
\text { change }\end{array}$ & $\begin{array}{l}\text { Changed } \\
\text { area (ha) }\end{array}$ & $\%$ change & $\begin{array}{l}\text { Annual } \\
\text { rate of } \\
\text { change }\end{array}$ \\
\hline Agricultural crops & 2649.99 & 69.52 & 176.67 & -909.43 & -14.07 & -60.63 & 1740.56 & 45.66 & 58.01 \\
\hline Barren land & 1510.1 & 126.38 & 100.67 & 2222.46 & 82.16 & 148.16 & 3732.56 & 312.39 & 124.41 \\
\hline Forest area & -4911.16 & -12.28 & -327.41 & -2253.97 & -6.43 & -150.26 & -7165.13 & -17.92 & -238.83 \\
\hline Settlement & 1017.26 & 136.89 & 67.82 & 759.52 & 43.15 & 50.63 & 1776.78 & 239.10 & 59.22 \\
\hline Waterbody & -266.19 & -17.16 & -17.75 & 181.42 & 14.12 & 12.09 & -84.77 & -5.47 & -2.82 \\
\hline
\end{tabular}

Note: (-) sign denotes decrease of magnitude of change of land-use category in different time frame 


\section{Forest cover loss associated with land-use conversion from 1988-2018}

Table 5 presents land-use conversions among interland-use classes between 1988 and 2018. The area under agriculture was 3811.92 ha in 2018 , and it was found that only 1096.37 ha of land remained unchanged while, and 2715.55 ha of agricultural lands were converted into other types of land-uses. Here, 1043.50 ha land area was converted into forest area and settlement 988.74 ha. About 484.51 ha of barren land came under re-plantation programs and about 255.18 ha was converted for agricultural use.

Within 30 years, the forest land has lost 9359.55 ha. From the 39989.29 ha forest area in 1988, about 30629.74 ha area remained unchanged, while about 3640.79 ha forest area was converted into agricultural land, about 893.49 ha area was converted into settlement and about 4371.31 ha land became barren area. In case of settlement, about 172.40 ha land was converted to waterbody, on the other hand, about 291.14 ha waterbody remained unchanged and the rest portion of the waterbody area was converted into other types of land-uses like forest area (584.06 ha), settlement (206.91 ha) and agricultural crops land (382.3) (Table 5 and Figure 4).

\section{Metrics calculation}

Classified LULC images of 1988, 2003 and 2018 were used as inputs in patch analyst extension software of Arc GIS 10.5 to calculate and analyze conversant landscape metrics for each class.

\section{Edge density}

Edge density is an indicator of landscape configuration for fragmentation analysis (class-level metrics). The study revealed that the edge density of forest area and agricultural crops rapidly increased from 1988-2018, while barren land and water bodies were almost consistent. At the same time period, edge density of the settlement decreased swiftly. This indicates that forest and agricultural cropland were converted into settlement and urbanization (Figure 5).

\section{Class area}

Class area indicates the sum of areas of all patches belonging to a particular landscape class. From 1988 to 2003 class area of forest increased rapidly, but it decreased slightly in 2018. On the other hand, from 1988-2003 patch area of settlement decreased drastically and remained unchanged till 2018. Similarly, the total patch areas of forest land increased and settlement decreased. Meanwhile, total patch areas of barren land, agricultural land, and waterbody did not change significantly (Figure 6).

Table 5. Land-use conversions among inter-land-use classes between 1988 and 2018 in Bandarban Sadar Upazila, Bangladesh

\begin{tabular}{|c|c|c|c|c|c|c|c|}
\hline & \multicolumn{7}{|c|}{ Land-use area (ha)-2018 } \\
\hline & \multirow{2}{*}{$\begin{array}{l}\text { Sum of area (ha) } \\
\text { Row labels }\end{array}$} & \multicolumn{6}{|c|}{$\begin{array}{cc}\text { Column labels } \\
\end{array}$} \\
\hline & & $\begin{array}{l}\text { Agricultural } \\
\text { crops }\end{array}$ & $\begin{array}{l}\text { Barren } \\
\text { land }\end{array}$ & $\begin{array}{l}\text { Forest } \\
\text { area }\end{array}$ & Settlement & $\begin{array}{l}\text { Water } \\
\text { body }\end{array}$ & $\begin{array}{l}\text { Grand } \\
\text { total }\end{array}$ \\
\hline & Agricultural land & 1096.37 & 235.24 & 1043.50 & 988.74 & 448.074 & 3811.92 \\
\hline & Agricultural crops & 1096.37 & & & & & 1096.37 \\
\hline & Agricultural crops to forest area & & & 1043.50 & & & 1043.50 \\
\hline & Agricultural crops to barren land & & 235.24 & & & & 235.24 \\
\hline & Agricultural crops to settlement & & & & 988.74 & & 988.74 \\
\hline & Agricultural crops to waterbody & & & & & 448.074 & 448.074 \\
\hline & Barren land & 255.18 & 207.18 & 484.51 & 147.44 & 100.54 & 1194.85 \\
\hline & Barren land & & 207.18 & & & & 207.18 \\
\hline & Barren land to settlement & & & & 147.44 & & 147.44 \\
\hline & Barren land to forest area & & & 484.51 & & & 484.51 \\
\hline & Barren land to agricultural crops & 255.18 & & & & & 255.18 \\
\hline & Barren land to waterbody & & & & & 100.54 & 100.54 \\
\hline & Forest land & 3640.79 & 4371.31 & 30629.74 & 893.49 & 453.96 & 39989.29 \\
\hline & Forest area & & & 30629.74 & & & 30629.74 \\
\hline & Forest area to agricultural crops & 3640.79 & & & & & 3640.79 \\
\hline & Forest area to settlement & & & & 893.49 & & 893.49 \\
\hline & Forest area to waterbody & & & & & 453.96 & 453.96 \\
\hline & Forest area to barren land & & 4371.31 & & & & 4371.30 \\
\hline & Settlement & 177.84 & 27.21 & 82.35 & 283.31 & 172.40 & 743.11 \\
\hline & Settlement & & & & 283.31 & & 283.31 \\
\hline & Settlement to agricultural crops & 177.84 & & & & & 177.84 \\
\hline & Settlement to barren land & & 27.21 & & & & 27.21 \\
\hline & Settlement to forest area & & & 82.35 & & & 82.35 \\
\hline & Settlement to waterbody & & & & & 172.40 & 172.40 \\
\hline & Waterbody & 382.30 & 86.47 & 584.06 & 206.91 & 291.14 & 1550.88 \\
\hline & Waterbody & & & & & 291.14 & 291.14 \\
\hline & Waterbody to agricultural crops & 382.30 & & & & & 382.30 \\
\hline & Waterbody to barren land & & 86.47 & & & & 86.47 \\
\hline & Waterbody to forest area & & & 584.06 & & & 584.06 \\
\hline & Waterbody to settlement & & & & 206.91 & & 206.91 \\
\hline & Grand Total & 5552.48 & 4927.41 & 32824.16 & 2519.89 & 1466.11 & 47290.05 \\
\hline
\end{tabular}




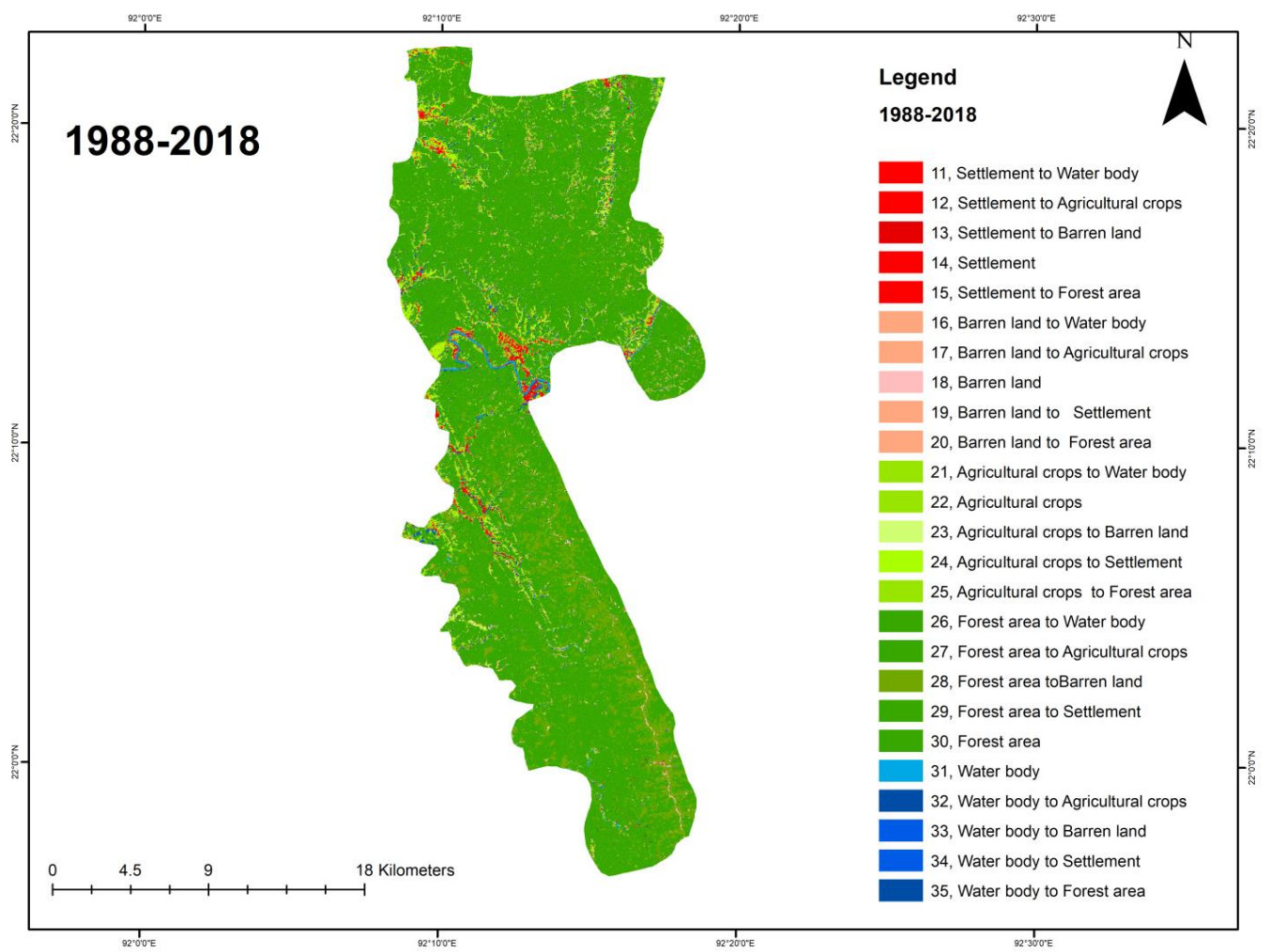

Figure 4. Land-use conversions among inter-landuse classes between 1988 and 2018 in of Bandarban Sadar Upazila, Bangladesh; image class $14,18,22,30$ and 31 represent original unconverted areas

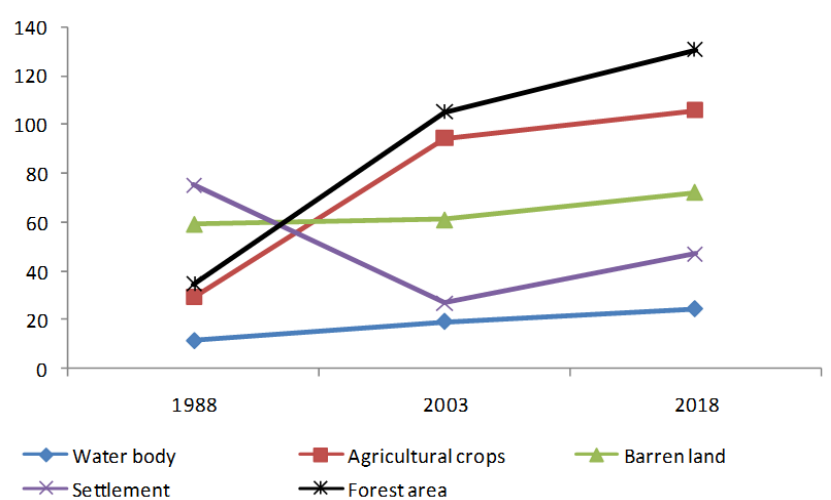

Figure 5. Edge density of Bandarban Sadar Upazila, Bangladesh from 1988-2018

\section{Mean Shape Index}

Mean shape Index (MSI) basically indicates shape complexity which is an indicator of fragmentation analysis. The study revealed that the MSI of settlement and agriculture had increasing trends and the waterbody had a partially increasing trend. The forest area had a drastic decrease during 1988-2003 while it got slightly restored in 2018. On the other hand, barren land was at first increased from 1988-2003 while it started declining 2003 onwards. MSI evaluation led to the understanding that shape complexity of agricultural crops and settlement increased while there was declining trend in forest areas (Figure 7).

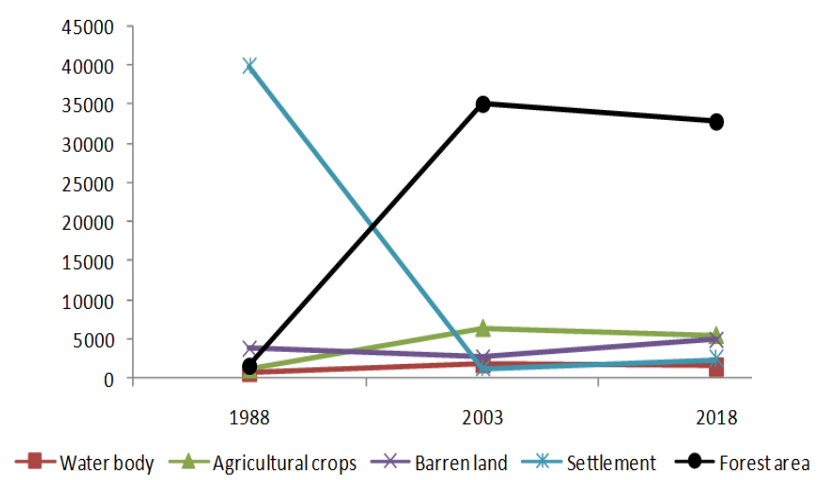

Figure 6. Class Area (CA) of Bandarban Sadar Upazila, Bangladesh from 1988-2018

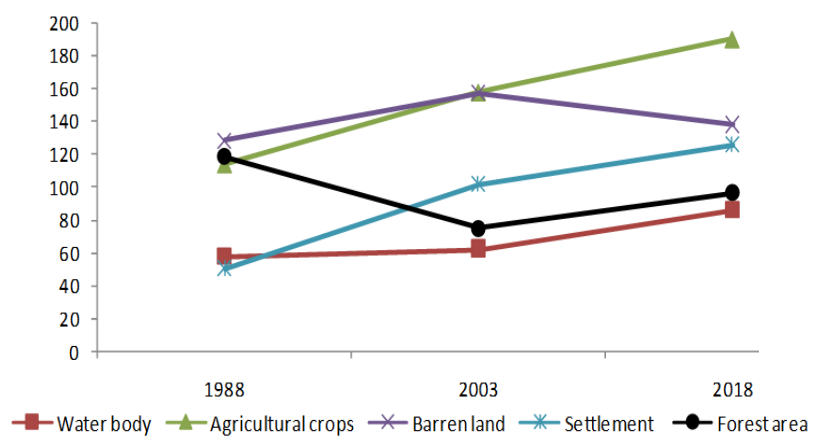

Figure 7. Mean Shape Index of Bandarban Sadar Upazila, Bangladesh from 1988-2018 
Landscape configuration and fragmentation analysis Spatial variation in land-use fragmentation

Land cover/land-use fragmentation varied with each land cover/land-use type as evident from the mean perimeter-area ratio (MPAR) of patches, mean patch size (MPS) and total edge (TE) as presented in Table 6. A more fragmented land cover/land-use pattern is generally associated with a decrease of the MPAR and an increase in total edge and MPS. Forest land became fragmented as its total edge area increased by $275.87 \%$ from $16469.6 \mathrm{~km}$ in 1988 to $61905 \mathrm{~km}$ in 2018 and the MPS increased 31290.05 ha. On the other hand, the mean perimeter area ratio declined from 1060.26 ha in 1988 to 188.48 ha in 2018.

The total edge of settlement declined $37.14 \%$ from 1988 to 2018, while MPS of settlement decreased by 37487.11 ha from 1988-2018, whereas the MPAR increased by $896.23 \%$ (Table 6). It can be concluded that the fragmentation area of the total forest patch increased and fragmented patch of settlement decreased and forest was converted to settlement and other land cover types. Smaller patches of settlement have become inter-connected and large portion of land cover has transformed to settlement (Figure 8).

Other classes of land cover also have changed with time. The total edge area of agricultural crops and MPS increased by $260.88 \%$ and $364.45 \%$ respectively, and MPAR decreased by $22.3 \%$, indicating the impact of fragmentation on agricultural crop land between 1988-2018. In the case of the waterbody, it was found that the MPAR increased by $6.34 \%$ and total edge area increased from $5557.23 \mathrm{~km}$ in 1988 to $11646.7 \mathrm{~km}$ in 2018 (Table 6).

\section{Changes in patch shape complexity of land cover/land-use categories}

Table 7 illustrates that the largest percentage of areaweighted mean shape index (AWMSI) of settlement increased by $150.27 \%$ from 1988-2018. The argument behind these can be linked to rapid forest destruction associated with agricultural intensification, shifting cultivation, unplanned settlement pattern in the study area. Due to the unplanned settlement, more complex and irregular shapes of settlement areas were created.

Similarly, the AWMPFD value (\% of change) for settlement from $1988-2018$ was $12.50 \%$, representing the increase in new irregular settlement patterns and the complex built-up patch shapes. Although, other practices like barren land, agricultural land, waterbody, and forest were less complex in irregularity from1988-2018 (Table 7).

AWMSI value for forest area declined by $18.26 \%$ and AWMPFD value by $7.56 \%$ from $1988-2018$. The forest patches became more irregular, exposed edges, extremely fragmented and the values indicate complex heterogeneous shapes due to human influence. Barren land patches, a number of which were located in open fields and agricultural activities, increased in AWMSI value by $7.35 \%$ and decreased in AWMPFD value by $0.59 \%$ leading to relatively simple circular shapes. The patches of Agricultural land's AWMSI increased (67.46\%) between 1988 to 2018, and its AWMPFD values did not change for the same period. The AWMSI and AWMPFD values of waterbodies increased by $49.29 \%$ and $1.20 \%$ respectively between 1988 to 2018 (Table 7).

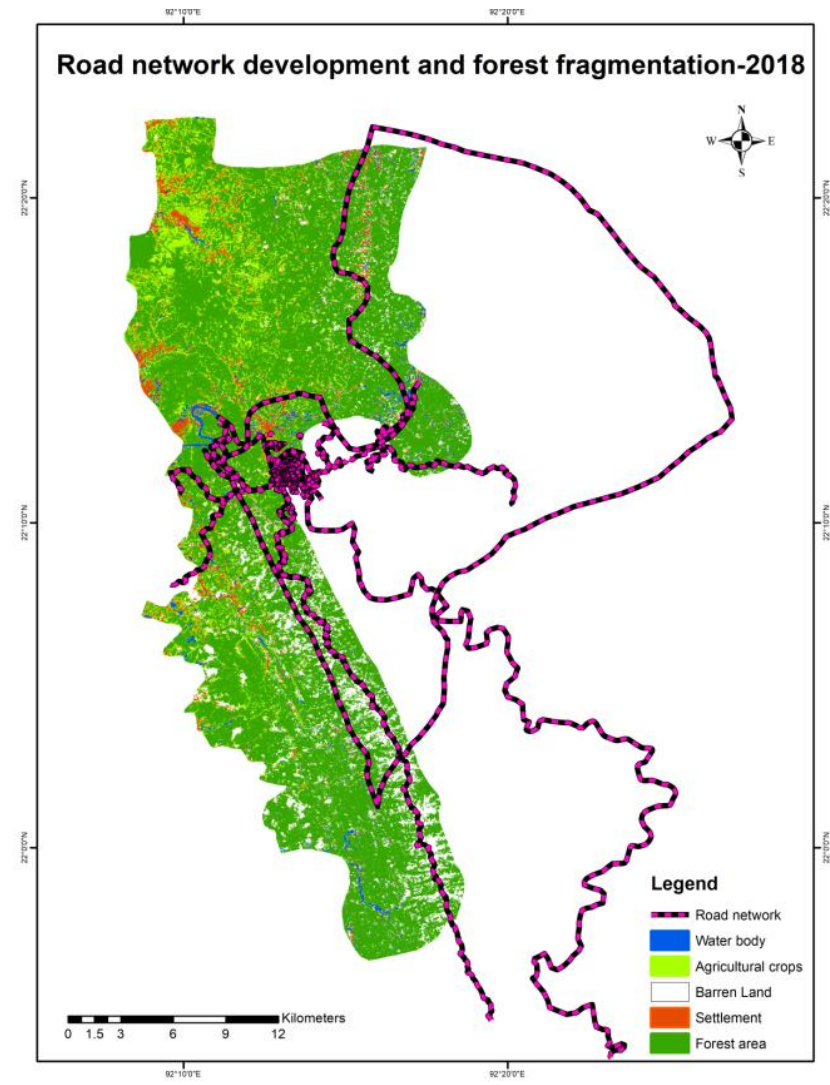

Figure 8. Development of road network and fragmentation of Bandarban Sadar Upazila, Bangladesh in 2018

Table 6. Spatial variation in land cover/land-use fragmentation

\begin{tabular}{|c|c|c|c|c|c|c|c|c|c|c|}
\hline \multicolumn{3}{|c|}{ Total edge $(\mathrm{km})$} & \multirow{3}{*}{$\begin{array}{l}\text { Change } \\
\text { from } \\
\text { 1988-2018 }\end{array}$} & \multicolumn{3}{|c|}{ Mean patch size (MPS)(ha) } & \multicolumn{4}{|c|}{ Mean perimeter-area ratio (MPAR) } \\
\hline \multirow{2}{*}{ Class } & TE & TE & & MPS & MPS & & MPAR & MPAR & Change & \\
\hline & 1988 & 2018 & & 1988 & 2018 & $\begin{array}{c}\text { from } \\
1988-2018\end{array}$ & 1988 & 2018 & $\begin{array}{c}\text { from } \\
\text { 1988-2018 }\end{array}$ & \\
\hline Waterbody & 5557.23 & 11646.7 & 109.58 & 745.24 & 1468.84 & 723.59 & 745.68 & 792.92 & 47.24 & 6.34 \\
\hline Agricultural crops & 13904.4 & 50178.3 & 260.88 & 1196.91 & 5559.08 & 4362.17 & 1161.69 & 902.63 & -259.06 & -22.3 \\
\hline Barren land & 28097 & 34275.3 & 21.99 & 3819.23 & 4931.2 & 1111.97 & 735.67 & 695.06 & -40.61 & -5.52 \\
\hline Settlement & 35649.7 & 22408.8 & -37.14 & 40011.7 & 2524.59 & -37487.1 & 89.09 & 887.61 & 798.52 & 896.31 \\
\hline Forest area & 16469.6 & 61905 & 275.87 & 1553.35 & 32843.4 & 31290.05 & 1060.26 & 188.48 & -871.78 & -82.22 \\
\hline
\end{tabular}


Table 7. Changes in patch shape complexity of land cover/land-use categories

\begin{tabular}{|c|c|c|c|c|c|c|c|c|c|}
\hline \multicolumn{5}{|c|}{ Area weight mean Shape index (AWMSI) } & \multicolumn{5}{|c|}{ Area Weighted Mean Patch Fractal Dimension (AWMPFD) } \\
\hline Class & $\begin{array}{c}\text { AWMSI } \\
1988\end{array}$ & $\begin{array}{c}\text { AWMSI } \\
2018\end{array}$ & $\begin{array}{c}\text { Change } \\
\text { 1988-2018 }\end{array}$ & $\begin{array}{c}\% \text { of } \\
\text { Change }\end{array}$ & Class & $\begin{array}{c}\text { AWMPFD } \\
1988\end{array}$ & $\begin{array}{c}\text { AWMPFD } \\
2018\end{array}$ & $\begin{array}{c}\text { Change } \\
\text { 1988-2018 }\end{array}$ & $\begin{array}{c}\% \text { of } \\
\text { change }\end{array}$ \\
\hline Waterbody & 57.42 & 85.72 & 28.3 & 49.29 & Waterbody & 1.67 & 1.69 & 0.02 & 1.20 \\
\hline Agricultural crops & 113.37 & 189.85 & 76.48 & 67.46 & Agricultural crops & 1.73 & 1.73 & 0.00 & 0.00 \\
\hline Barren land & 128.25 & 137.68 & 9.43 & 7.35 & Barren land & 1.70 & 1.69 & -0.01 & -0.59 \\
\hline Settlement & 50.27 & 125.81 & 75.54 & 150.27 & Settlement & 1.52 & 1.71 & 0.19 & 12.50 \\
\hline Forest area & 117.88 & 96.36 & -21.52 & -18.26 & Forest area & 1.72 & 1.59 & -0.13 & -7.56 \\
\hline
\end{tabular}

This finding shows that forest destruction destroys valuable natural resources of the study areas. As in the current case, swift collapse of evergreen and semievergreen forest area was recorded between 1988-2018. Increase in settlement can be considered the main reason behind this. People from different areas migrate to Chittagong Hill Tracts and for settlement in combination with the seen establishment of different organizations, schools, colleges, industries, etc. And the corresponding increase in population has led to rapid forest destruction. Forest and agricultural areas were thus converted into settlements and divided into many smaller patch areas which led to the increase of AWMSI and AWMPFD of settlement areas.

\section{Landscape diversity and probability distribution model for different agro-horticultural practices and artificial plantation}

The decrease in Shannon's Diversity Index (SHDI) and Shannon Evenness Index (SHEI) from 1988 to 2018 (Table 8) indicates decrease in landscape heterogeneity and evenness. This was contrary to the expectation that the decrease in forest land would cause reduction in landscape diversity. It can be concluded that once the huge landscape diversity of Chittagong Hill Tracts, Bandarban gradually declined with the passage of time and deforestation and fragmentation (Table 8). The gradual decrease in SHEI from 1988-2018 also indicates that the classes of map units were not uniformly distributed in the study area reflecting the differences in sizes of certain land cover/land-use on the landscape with some practices dominating others at the landscape level.

In 2018, agro-horticultural plantation was the main cause for reducing landscape diversity. Natural forest was replaced by human-modified plantation of teak, horticultural practices, agroforestry practices, etc. To classify different agro-horticultural practices, probability distribution map was generated using satellite imagery and topographic variables with Arc GIS10.5.

The maximum amount of land was found to be deployed for teak (Tectona grandis) plantation (Figure 9). After teak plantation, agroforestry was practiced, and together were the top two causes of natural forest destruction. Homestead plantation and horticultural practices occupied additionally outsized portion of Bandarban Sadar Upazila. Though the percentage of jhum cultivation was not high, it spread vastly across all Upazila. Fast-growing tree species were planted by the government through different plantation programs. Naturally, different types of bamboos were found in all hilly areas and were also planted artificially in some places.

In conclusion, it can be enunciated that spatial/ landscape metrics are useful tools to narrate the landscape structure with various aspects especially in fragmentation analysis. Bandarban Sadar Upazila has been undergoing severe deforestation and degradation since the beginning of 1988 due to habitat destruction, fragmentation, shifting cultivation, over-exploitation, encroachment, and agroforestry practices. An enormous amount of forest land and semi-natural vegetation were converted to other land cover types. The increase in population, as well as settlement and urbanization, made forested areas more complex in shape and fragmented. Increasing heterogeneity and fragmentation of habitat were identified through landscape metrics for 1988, 2003, and 2018. The growth pattern of fragmented patches, uniformity, and irregularity, and change in shape complexity was illustrated by using AWMSI and AWMPFD in this study.

Rapid conversion of forest area into agro-horticultural area in an unplanned and unauthorized way, aggravated by intensified shifting cultivation as supported by AWMSI and AWMPFD measurements, gives an urgent message to policy-makers about the extent of rapid fragmentation and natural forest loss in the area. It was also noticed that, spatial configuration changes (as indicated by change in the number of patches, MPS, and total edge) the diversity of landscape. From 1988-2018, forest area decreased swiftly and decreased SHDI and SHEI index. Further, it can be said that settlement expansion, agroforestry practices, and artificial plantation in hilly areas increased fragmentation extent and reduce natural biodiversity.

Table 8. Landscape diversity statistics in Bandarban Sadar Upazila, Bangladesh

\begin{tabular}{ccc}
\hline Year & $\begin{array}{c}\text { Shannon's } \\
\text { Diversity Index }\end{array}$ & $\begin{array}{c}\text { Shannon's } \\
\text { Evenness Index }\end{array}$ \\
\hline 2018 & 0.615 & 0.382 \\
2003 & 0.878 & 0.545 \\
1988 & 1.004 & 0.624 \\
\hline
\end{tabular}




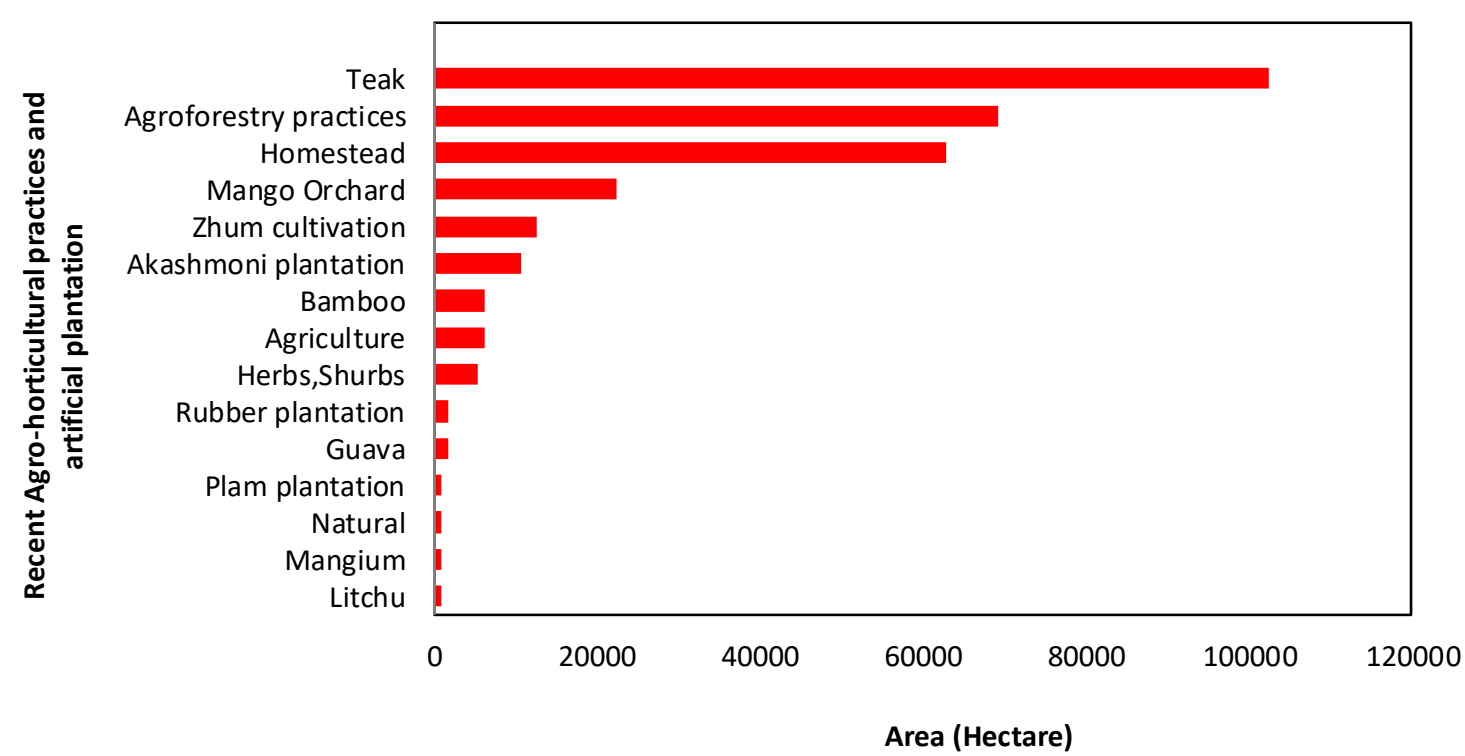

Figure 9. Main reasons for natural forest destruction in Bandarban Sadar Upazila-2018

This study tries to draw attention to rapid fragmentation, biodiversity loss, and poor management of natural resources which has driven vast areas of previously forest land now turned to unplanned settlements, barren hills, or agro-horticultural practices. Appropriate intervention from concerned authorities is required to save remnant natural evergreen and semi-evergreen forest of Bandarban Sadar Upazila, Chittagong Hill Tracts, Bangladesh.

\section{ACKNOWLEDGEMENTS}

The authors wanted to offer thanks Prof. Mohammad Mosharraf Hossain, Institute of Forestry and Environmental Sciences, University of Chittagong, Bangladesh for valuable comments and suggestions at the time of preparing this manuscript. The authors are also grateful to Kamrul Islam, The University of Tokyo, Japan; for his valuable criticism. The author also expresses that there is no potential conflict of interest.

\section{REFERENCES}

Baten MA, Khan NA, Ahammad R, Misbahuzzaman K. 2010. Village common forests in Chittagong Hill Tracts, Bangladesh: balance between conservation and exploitation. Unnayan Onneshan-The Innovators, Dhanmondi, Dhaka, Bangladesh.

Bhusal YR, Thapa GB, Weber KE. 1998. Thailand's disappearing forests: the challenge to tropical forest conservation. Intl J Environ Pollut 9 (2-3): 198-212. DOI: 10.1504/IJEP.1998.028242

Biswas S, Swanson ME, Vacik H. 2012. Natural resources depletion in hill areas of Bangladesh: A review. J Mount Sci 9 (2): 147-156. DOI: 10.1007/s11629-012-2028-z

Broadbent EN, Asner GP, Keller M, Knapp DE, Oliveira PJ, Silva JN. 2008. Forest fragmentation and edge effects from deforestation and selective logging in the Brazilian Amazon. Biol Conserv 141 (7): 1745-1757. DOI: 10.1016/j.biocon.2008.04.024

Chianga SH, Valdeza M, Chena CF. 2016. Forest tree species distribution mapping using Landsat satellite imagery and topographic variables with the maximum entropy method in Mongolia. Intl Arch Photogrammetry Remote Sens Spat Inf Sci 8. DOI: 10.5194/isprsarchives-XLI-B8-593-2016.

Chowdhury FI, Islam K, Faroque MA, Islam KN, Rahman MF, Arif MTA, Nath TK, Jashimuddin M. 2020. Assessing the impacts of comanagement on protected area landscape under socio-imagery lens: evidence from Bangladesh. J Sustain For. DOI: 10.1080/10549811.2020.1747497.

Donovan TM, Jones PW, Annand EM, Thompson FR III. 1997. Variation in local-scale edge effects: mechanisms and landscape context. Ecology 78 (7): 2064-2075. DOI: 10.1890/00129658(1997)078[2064:VILSEE]2.0.CO;2

Echeverria C, Coomes DA, Hall M, Newton AC. 2008. Spatially explicit models to analyze forest loss and fragmentation between 1976 and 2020 in southern Chile. Ecol Model 212 (3-4): 439-449. DOI: 10.1016/j.ecolmodel.2007.10.045

Hansen M, Franklin S, Woudsma C, Peterson M. 2001. Caribou habitat mapping and fragmentation analysis using Landsat MSS, TM, and GIS data in the North Columbia Mountains, British Columbia, Canada. Remote Sens Environ 77 (1): 50-65. DOI: 10.1016/S00344257(01)00193-6

Harper GJ, Steininger NK, Tucker CJ, Juhn D, Hawkins F. 2007. Fifty years of deforestation and forest fragmentation in Madagascar. Environ Conserv 34 (4): 325-333. DOI: DOI: 10.1017/S0376892907004262

Jha C, Goparaju L, Tripathi A, Gharai B, Raghubanshi A, Singh J. 2005. Forest fragmentation and its impact on species diversity: an analysis using remote sensing and GIS. Biodivers Conserva 14 (7): 16811698. DOI: 0.1007/s10531-004-0695-y

Kowe P, Pedzisai E, Gumindoga W, Rwasoka D. 2015. An analysis of changes in the urban landscape composition and configuration in the Sancaktepe District of Istanbul Metropolitan City, Turkey using landscape metrics and satellite data. Geocarto Intl 30 (5): 506-519. DOI: $10.1080 / 10106049.2014 .905638$

McGarigal K. 1995. FRAGSTATS: Spatial pattern analysis program for quantifying landscape structure. US Department of Agriculture, Forest Service, Pacific Northwest Research Station. Corvallis, OR.

McGarigal K, Cushman S, Ene E. 2012. FRAGSTATS v4: Spatial pattern analysis program for categorical and continuous maps. University of Massachusetts, Amherst, MA, USA. 
Morris RJ. 2010. Anthropogenic impacts on tropical forest biodiversity: a network structure and ecosystem functioning perspective. Phil Trans R Soc B Biol Sci 365 (1558): 3709-3718. DOI: 10.1098/rstb.2010.0273

Öckinger E, Bergman KO, Franzén M, Kadlec T, Krauss J, Kuussaari M, Pöyry J, Smith HG, Steffan-Dewenter I, Bommarco R. 2012. The landscape matrix modifies the effect of habitat fragmentation in grassland butterflies. Landsc Ecol 27 (1): 121-131. DOI: 10.1007/s10980-011-9686-z

Rasul G, Thapa GB. 2006. Financial and economic suitability of agroforestry as an alternative to shifting cultivation: The case of the Chittagong Hill Tracts, Bangladesh. Agric Syst 91 (1-2): 29-50. DOI: 10.1016/j.agsy.2006.01.006
Rasul G, Thapa GB, Zoebisch MA. 2004. Determinants of land-use changes in the Chittagong Hill Tracts of Bangladesh. Appl Geogr 24 (3): 217-240. DOI: 10.1016/j.apgeog.2004.03.004

Rodewald AD. 2003. The importance of land-uses within the landscape matrix. Wildl Soc Bull 31 (2): 586-592.

Tchoumbou MA, Mayi MPA, Malange EN, Foncha FD, Kowo C, Fru-cho J, Tchuinkam T, Awah-Ndukum J, Dorazio R, Anong DN. 2020. Effect of deforestation on prevalence of avian haemosporidian parasites and mosquito abundance in a tropical rainforest of Cameroon. Intl J Parasitol 50 (1): 63-73. DOI: 10.1016/j.ijpara.2019.10.006

Zapfack L, Weladji RB, Djomo CC, Nyako MC, Nasang JM, Tagnang NM, Mbobda RBT. 2020. Biodiversity and carbon sequestration potential in two types of tropical rainforest, Cameroon. Acta Oecol 105: 103562. DOI: 10.1016/j.actao.2020.103562. 